\title{
Vanadium pentoxide induces pulmonary inflammation and tumor promotion in a strain-dependent manner
}

\author{
Elizabeth A Rondini' ${ }^{1}$ Dianne M Walters ${ }^{2}$ and Alison K Bauer*1
}

\begin{abstract}
Background: Elevated levels of air pollution are associated with increased risk of lung cancer. Particulate matter (PM) contains transition metals that may potentiate neoplastic development through the induction of oxidative stress and inflammation, a lung cancer risk factor. Vanadium pentoxide $\left(\mathrm{V}_{2} \mathrm{O}_{5}\right)$ is a component of PM derived from fuel combustion as well as a source of occupational exposure in humans. In the current investigation we examined the influence of genetic background on susceptibility to $\mathrm{V}_{2} \mathrm{O}_{5}$-induced inflammation and evaluated whether $\mathrm{V}_{2} \mathrm{O}_{5}$ functions as a tumor promoter using a 2-stage (initiation-promotion) model of pulmonary neoplasia in mice.

Results: $\mathrm{A} / \mathrm{J}, \mathrm{BALB} / \mathrm{CJ}(\mathrm{BALB})$, and $\mathrm{C57BL/6J}$ (B6) mice were treated either with the initiator 3-methylcholanthrene (MCA; $10 \mu \mathrm{g} / \mathrm{g}$; i.p.) or corn oil followed by 5 weekly aspirations of $\mathrm{V}_{2} \mathrm{O}_{5}$ or PBS and pulmonary tumors were enumerated 20 weeks following MCA treatment. Susceptibility to $\mathrm{V}_{2} \mathrm{O}_{5}$-induced pulmonary inflammation was assessed in bronchoalveolar lavage fluid (BALF), and chemokines, transcription factor activity, and MAPK signaling were quantified in lung homogenates. We found that treatment of animals with $\mathrm{MCA}$ followed by $\mathrm{V}_{2} \mathrm{O}_{5}$ promoted lung tumors in both $\mathrm{A} / \mathrm{J}\left(10.3 \pm 0.9\right.$ tumors/mouse) and BALB $(2.2 \pm 0.36)$ mice significantly above that observed with MCA/PBS or $\mathrm{V}_{2} \mathrm{O}_{5}$ alone $(P<0.05)$. No tumors were observed in the $\mathrm{B} 6$ mice in any of the experimental groups. Mice sensitive to tumor promotion by $\mathrm{V}_{2} \mathrm{O}_{5}$ were also found to be more susceptible to $\mathrm{V}_{2} \mathrm{O}_{5}$-induced pulmonary inflammation and hyperpermeability (A/J>BALB>B6). Differential strain responses in inflammation were positively associated with elevated levels of the chemokines KC and MCP-1, higher NFKB and c-Fos binding activity, as well as sustained ERK1/2 activation in lung tissue.

Conclusions: In this study we demonstrate that $\mathrm{V}_{2} \mathrm{O}_{5}$, an occupational and environmentally relevant metal oxide, functions as an in vivo lung tumor promoter among different inbred strains of mice. Further, we identified a positive relationship between tumor promotion and susceptibility to $\mathrm{V}_{2} \mathrm{O}_{5}$-induced pulmonary inflammation. These findings suggest that repeated exposures to $\mathrm{V}_{2} \mathrm{O}_{5}$ containing particles may augment lung carcinogenesis in susceptible individuals through oxidative stress mediated pathways.
\end{abstract}

\section{Background}

Lung cancer is the leading cause of cancer mortality in the U.S. and worldwide [1]. Although cigarette smoke is the main risk factor for lung cancer development, approximately $10-15 \%$ of cases occur in never-smokers, implicating other important environmental, occupational, and/or genetic factors [2-4]. Epidemiology studies

* Correspondence: akbauer@msu.edu

1 Department of Pathobiology and Diagnostic Investigation and Center for Integrative Toxicology, Michigan State University, East Lansing, MI, 48824, USA Full list of author information is available at the end of the article have suggested that long-term exposure to elevated levels of particulate air pollution increases the risk of and mortality due to lung cancer [5-8]. Particulate matter (PM) is a complex mixture of particles that vary in physiochemical properties and are further classified according to the aerodynamic size $\left(\mathrm{PM}_{2.5}=<2.5 \mu \mathrm{m} ; \mathrm{PM}_{10}=\leq 10 \mu \mathrm{m}\right)$ $[9,10] . \mathrm{PM}_{2.5}$ consists primarily of combustion products derived from automobiles and the burning of coal, fuel oil, and wood [9]. Most adverse health effects have been attributed to this fraction, due to the ability to penetrate 
deep within the alveolar region of the lung [11]. Using models developed by the World Bank, Cohen et. al. [12] predicted that $5 \%$ of respiratory cancer mortality worldwide is due to $\mathrm{PM}_{2.5}$.

The mechanism(s) contributing to increased lung cancer risk by PM have not been fully characterized, although it has been suggested that pulmonary inflammation mediated by particle-induced oxidative stress may play an important role [13,14]. Generation of reactive oxygen and nitrogen species (ROS/RNS) either directly or through activation of phagocytes can cause oxidative damage to DNA leading to initiation of cancer [14]. Additionally, ROS may potentiate tumor development by stimulating production of pro-inflammatory mediators that can promote expansion of initiated cells by influencing cell proliferation and apoptosis [14]. Oxidative stress induced by PM is dependent on both the surface area of the particle as well as its chemical composition [15]. Transition metals, and in particular vanadium compounds, have been implicated as the active constituents meditating oxidative lung injury in rodents exposed to residual fly oil ash (ROFA) [16-18] as well as in some studies using concentrated ambient air particles [19].

Vanadium pentoxide $\left(\mathrm{V}_{2} \mathrm{O}_{5}\right)$ is the most common commercial form of vanadium [20]. $\mathrm{V}_{2} \mathrm{O}_{5}$ is released into the environment during oil and coal combustion and from metallurgical works [20]. Occupational exposure can be significant in the petrochemical, mining, and steel industries [20]. Additionally, military personnel and the general public can be exposed to high levels of vanadium as a result of incidental or intentional burning of fuel oils, such as exposures that occurred during the Kuwait oil fires in 1991 [21]. Adverse respiratory effects have been reported in humans, primates, and rodents exposed acutely to $\mathrm{V}_{2} \mathrm{O}_{5}$. Coughing, wheezing, chest pain, bronchitis, and asthma-like symptoms as well as impaired lung function occurred in humans exposed to high levels of $\mathrm{V}_{2} \mathrm{O}_{5}$-containing dust [22-25]. In primates, inhalation of $\mathrm{V}_{2} \mathrm{O}_{5}$ particles increased bronchoaveolar polymorphonuclear neutrophils (PMNs) and impaired pulmonary function [26], and in rodents, inhalation or intratracheal administration induced PMN influx, synthesis of proinflammatory mediators, as well as pulmonary fibrosis [27-30].

Occupational and ambient exposure to vanadium has been associated with an increase in biological markers for oxidative DNA damage [31,32], however limited data are available evaluating an association between $\mathrm{V}_{2} \mathrm{O}_{5}$ exposure on lung cancer risk [33,34]. In vitro studies suggest that vanadium functions as both an initiator and promoter of morphological transformation in cultured cell lines [35]. In a National Toxicology Program (NTP) study, continuous inhalation of $\mathrm{V}_{2} \mathrm{O}_{5}$ (24 months inhalation; $1-4$ $\left.\mathrm{mg} / \mathrm{m}^{3}\right)$ resulted in a significant increase $(\sim 50 \%)$ in the incidence of alveolar/bronchiolar neoplasms in both male and female B6C3F1 mice [30]. Although this study demonstrated the carcinogenic potential of $\mathrm{V}_{2} \mathrm{O}_{5}$, long-term continuous exposure was required before tumors developed and no dose response was observed, which suggests $\mathrm{V}_{2} \mathrm{O}_{5}$ may be promoting spontaneous tumors. In addition, different mouse strains were not assessed, which can greatly influence pulmonary responses to environmental pollutants [36] as well as susceptibility to carcinogenesis $[37,38]$.

This study was conducted to further evaluate the role of $\mathrm{V}_{2} \mathrm{O}_{5}$ on pulmonary neoplasia among different inbred strains of mice. Using a two-stage (initiation-promotion) model, we hypothesized that inflammation induced by sub-chronic $\mathrm{V}_{2} \mathrm{O}_{5}$ administration would promote tumorigenesis in susceptible strains. Three strains of mice were included in this study that display altered susceptibility to chemical carcinogenesis: A/J mice are sensitive, BALB are intermediate, whereas B6 mice are resistant to most short term chemically-induced carcinogenesis protocols (eg. not initiatable using MCA) [37-39]. These same three strains also have similar differential susceptibility in chronic pulmonary inflammation models [40-42]. Results from this study demonstrate that $\mathrm{V}_{2} \mathrm{O}_{5}$ functions as an in vivo lung tumor promoter in both $\mathrm{A} / \mathrm{J}$ and BALB mice. Further, we demonstrate a positive relationship between tumor promotion and susceptibility to $\mathrm{V}_{2} \mathrm{O}_{5}$-induced inflammation, involving the induction of the chemokines $\mathrm{KC}$ and $\mathrm{MCP}-1$, the transcription factors $\mathrm{NFK}_{\mathrm{B}}$ and cFos, as well as sustained activation of ERK1/2 in pulmonary tissue.

\section{Methods}

\section{Animal husbandry}

Male A/J, BALB/cJ (BALB), C57BL/6J (B6) mice were purchased from Jackson Laboratories (Bar Harbor, ME) at 5-6 weeks of age. Animals were housed in plastic, filtercapped cages containing hardwood bedding and maintained in temperature $\left(23 \pm 2^{\circ} \mathrm{C}\right)$ and humidity $(40-60 \%)$ controlled rooms with a 12 hour light/dark cycle. Animals were given standard laboratory chow (Teklan foods, Indianapolis, IN) and spring water ad libitum and were assessed daily for health status. All mice were allowed one week to acclimatize prior to treatment. Animal use was conducted in AAALAC-accredited facilities and in accordance with the regulatory guidelines of the Michigan State University All University Committee on Animal Use and Care.

\section{Preparation and Administration of Vanadium Pentoxide}

Pulmonary administration of vanadium pentoxide ( $>99.9 \%$, Sigma-Aldrich, St. Louis, MO) was performed 
by oropharyngeal aspiration as previously described [43]. Briefly, $\mathrm{V}_{2} \mathrm{O}_{5}$ was suspended in sterile-filtered Dulbecco's phosphate buffered saline (10 mM PBS, pH 7.4), sonicated for 20 minutes, then further diluted to a working concentration of $2 \mathrm{mg} / \mathrm{mL}$. Prior to aspirations mice were anesthetized using $3 \%$ isoflurane in $1-2 \mathrm{~L} / \mathrm{min}$ oxygen, and $\mathrm{V}_{2} \mathrm{O}_{5}(4 \mathrm{mg} / \mathrm{kg}$ body weight) was administered following the methods of Foster et. al. [43]. This dose was chosen based on preliminary dose response studies using protocol 2 (Fig. 1B) described below (data not shown), as well as previous acute lung injury models $[28,29]$. Control animals received PBS alone ( $50 \mu \mathrm{L} /$ mouse). $\mathrm{V}_{2} \mathrm{O}_{5}$ suspensions were prepared fresh prior to use and administered to animals within two hours of preparation.

A. Protocol 1. $\mathrm{V}_{2} \mathrm{O}_{5}$-induced tumor promotion.

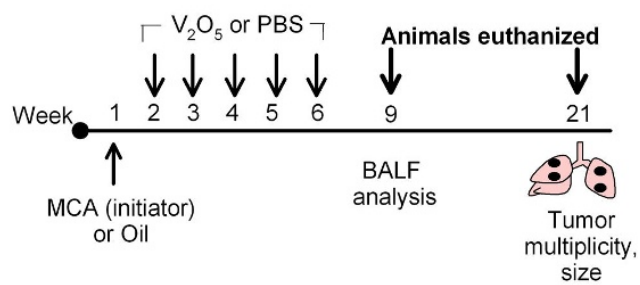

B. Protocol 2. $\mathrm{V}_{2} \mathrm{O}_{5}$-induced chronic inflammation.

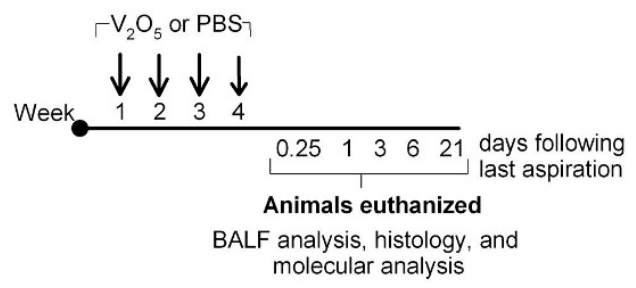

C. Protocol 3. Strain responses in inflammation to MCA/PBS.

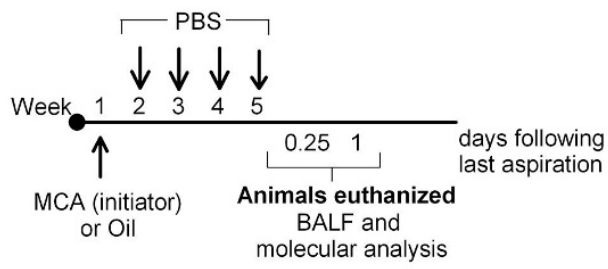

Figure 1 Experimental protocols. A.) $\mathrm{V}_{2} \mathrm{O}_{5}$ was evaluated as a tumor promoter using a two-stage carcinogenesis model. MCA suspended in corn oil $(10 \mu \mathrm{g} / \mathrm{g})$ was administered to initiate carcinogenesis followed by 5 weekly aspirations of $\mathrm{V}_{2} \mathrm{O}_{5}(4 \mathrm{mg} / \mathrm{kg}$, promoter) or PBS. B.) A/J,

$\mathrm{BALB}$, and $\mathrm{B} 6$ mice were exposed to 4 weekly aspirations of $\mathrm{V}_{2} \mathrm{O}_{5}$ and sacrificed at select time points to assess pulmonary inflammation. $C$.) A/J, BALB, and B6 mice were administered MCA $(10 \mu \mathrm{g} / \mathrm{g})$ or oil and then exposed to 4 weekly aspirations of PBS and sacrificed at select time points to assess pulmonary inflammation.

\section{Experimental Procedures}

The experimental designs utilized in this study are depicted in Figure 1. Protocol 1 (Fig. 1A) was conducted to investigate whether sub-chronic exposure to $\mathrm{V}_{2} \mathrm{O}_{5}$ would promote pulmonary carcinogenesis using a twostage (initiation-promotion) model. Mice were injected ip. (10 $\mu \mathrm{g} / \mathrm{g}$ body weight) with the carcinogen MCA (Sigma, St. Louis, MO) dissolved in corn oil or with corn oil alone. Beginning one week later, mice were treated with 5 weekly aspirations of either $\mathrm{V}_{2} \mathrm{O}_{5}(4 \mathrm{mg} / \mathrm{kg})$ or PBS as described above. To assess tumor promotion, animals were sacrificed 20 weeks following MCA treatment; the lungs were perfused with saline then inflated and fixed in Tellyesniczky's fixative for $48 \mathrm{hrs}$. Tumors were enumerated using an Olympus SZX7 stereomicroscope (Olympus; Center Valley, PA) and sized with digital calipers (Mitutoyo Corporation; Japan). Using this protocol, pulmonary inflammation was additionally assessed in A/J mice 21 days following the last aspiration as described below.

To assess strain differences in inflammation, (protocol 2, Fig. 1B), mice were aspirated once per week for 4 weeks with $\mathrm{V}_{2} \mathrm{O}_{5}(4 \mathrm{mg} / \mathrm{kg})$ or PBS. At selected time intervals $(6$ $\mathrm{hr}, 1,3,6$, and 21 days) following the last dose, bronchoaveolar lavage fluid (BALF) was collected to quantify differences in cellular infiltrates and protein content, a marker of hyperpermeability, as described previously [44]. At each time point, the right lobes were snap frozen in liquid nitrogen and stored at $-80^{\circ} \mathrm{C}$ and the left lobe was either snap frozen and stored or inflated with and fixed overnight in 10\% neutral buffered formalin for histological examination.

Because several studies demonstrated that MCA can induce p38 MAP Kinase, intracellular oxidants, as well as transcription factor activity in HepG2 cells (a hepatoma cell line) [45-47], an additional control experiment was conducted to determine whether carcinogen (MCA) administration influences pulmonary inflammation between strains. Mice were injected ip. with MCA $(10 \mu \mathrm{g} /$ g) dissolved in corn oil or oil alone, then aspirated with 4 weekly doses of PBS (Protocol 3, Fig. 1C) and sacrificed 6 $\mathrm{hr}$ or 1 day following the last aspiration. BALF was assessed for protein content and cellular infiltrate as described above.

\section{Immunohistochemical Detection of PMNs}

A neutrophil-specific marker (sc-59338) and ABC detection kit (sc-2019) were purchased from Santa Cruz Biotechnology (Santa Cruz, CA). Left lungs were fixed in $10 \%$ NBF for 24 hrs, processed using standard histological procedures, embedded, then cut into $5 \mu \mathrm{m}$ sections. Strain differences in pulmonary neutrophil infiltration were evaluated using peroxidase biotin-streptavidin immunohistochemistry, and bound enzyme was visual- 
ized using the chromagen 3-3'-diaminobenzidine (DAB). Tissues were then lightly counterstained in Gill's hematoxylin.

Analysis of the chemokines KC, MIP-2, and MCP-1 by ELISA ELISA kits for keratinocyte-derived chemokine (KC, CXCL1), macrophage inflammatory protein-2 (MIP-2, CXCL2), and monocyte chemoattractant protein 1 (MCP-1, CCL2) were purchased from R\&D systems (Minneapolis, MN). Protein was prepared by homogenizing lungs in ice-cold RIPA buffer (10 mM PBS, 0.5\% SDS, $0.5 \%$ sodium deoxycholate) containing protease inhibitors (Sigma, St. Louis, MO). Homogenates were centrifuged at $13,000 \times g$ for $10 \mathrm{~min}$ at $4^{\circ} \mathrm{C}$, and protein was quantified using the DC protein assay (BioRad; Carlsbad, CA). For chemokine analysis 25-50 $\mu \mathrm{g}$ of RIPA extracted protein was used in accordance with manufacturer's instructions. Absorbance was measured at $450 \mathrm{~nm}$ using a VersaMax microplate reader (Molecular Devices, Sunnyvale, CA). All data are presented as $\mathrm{pg} / \mathrm{mg}$ protein.

\section{Transcription factor assay for nuclear NFKB and c-Fos activity}

Nuclear protein was prepared from the left lung of mice using the TransAM nuclear extraction kit (Active Motif; Carlsbad, CA) and quantified with the DC protein assay (Biorad; Carlsbad, CA). Strain differences in binding of NFkB (p65 subunit) and AP-1 (c-Fos) were then measured from $8 \mu \mathrm{g}$ of nuclear protein using TransAM Transcription Factor ELISA kits (Active Motif; Carlsbad, CA). Absorbance was measured at $450 \mathrm{~nm}$ using a VersaMax microplate reader (Molecular Devices, Sunnyvale, CA).

\section{Immunoblotting analyses for MAPK activation}

Primary antibodies specific for MAPKs were purchased from Cell Signaling (Danvers, MA) and secondary antibodies from Pierce (Thermo Fisher; Rockford, IL). Pro- tein was prepared from right lungs as described above. Samples $(100 \mu \mathrm{g}$ protein) were resolved on $12.5 \%$ SDS polyacrylamide gels. Following transfer, PVDF membranes were blocked for $1 \mathrm{hr}$ at room temperature in 5\% nonfat dry milk, and then incubated with primary antibodies to detect phosphorylated ERK1/2, JNK1/2, or p38 overnight at $4^{\circ} \mathrm{C}$. After washing, blots were incubated in secondary antibody linked to horseradish peroxidase for $1 \mathrm{hr}$ at room temperature, and bands were detected using chemiluminescence. Images were captured using BioRad ChemiDoc illumination system (BioRad; Carlsbad, CA). Following detection, membranes were stripped in Restore stripping buffer (Thermo Fisher; Rockford, IL) then reprobed for total MAPK using procedures described above. Densitometry of bands were quantified with BioRad Quality One software and phosphorylated proteins were normalized to the respective total MAPK prior to statistical analyses.

\section{Statistical analyses}

All statistical analyses were conducted using SAS statistical software (SAS institute version 8.2, Cary, North Carolina). Time- and strain- dependent changes in BALF protein, cellularity, chemokines, nuclear transcription factor activity, protein densitometry, and tumor multiplicity/size were analyzed using an analysis of variance (ANOVA). When statistical differences were detected $(P$ $<0.05$ ), comparisons of means were analyzed using the least significant difference (LSD) method. All data are presented as mean \pm SEM.

\section{Results}

Sub-chronic administration of $\mathrm{V}_{2} \mathrm{O}_{5}$ promotes pulmonary tumorigenesis in $\mathrm{A} / \mathrm{J}$ and $\mathrm{BALB}$ mice

Strain differences in tumor multiplicity and size are presented in Table 1. We found that $\mathrm{V}_{2} \mathrm{O}_{5}$ functions primar-

Table 1: Lung tumor multiplicity and size (in parenthesis) among inbred mice following sub-chronic $\mathrm{V}_{2} \mathrm{O}_{5}$ exposure.a, b, c, d

\begin{tabular}{|c|c|c|c|c|}
\hline \multirow[b]{2}{*}{ Strain } & \multicolumn{2}{|c|}{ Corn Oil (Control) } & \multicolumn{2}{|c|}{ MCA-treated } \\
\hline & PBS & $\mathbf{V}_{\mathbf{2}} \mathbf{O}_{5}$ & PBS & $\mathbf{V}_{\mathbf{2}} \mathbf{O}_{5}$ \\
\hline$A / J$ & $0.0 \pm 0.0$ & $0.50 \pm 0.50$ & $\begin{array}{c}3.3 \pm 0.75^{\#} \\
(0.72 \pm 0.036)^{\#}\end{array}$ & $\begin{array}{c}10 \pm 1.4^{* \#} \\
(0.72 \pm 0.032)^{\#}\end{array}$ \\
\hline BALB & $0.0 \pm 0.0$ & $0.0 \pm 0.0$ & $\begin{array}{c}0.78 \pm 0.28 \\
(0.49 \pm 0.039)\end{array}$ & $\begin{array}{c}2.2 \pm 0.36^{*} \\
(0.63 \pm 0.068)\end{array}$ \\
\hline
\end{tabular}

a $A / J, B A L B$, and $B 6$ mice were treated with or without the initiator MCA $(10 \mu \mathrm{g} / \mathrm{g})$, followed by sub-chronic administration of $\mathrm{V}_{2} \mathrm{O}_{5}(4 \mathrm{mg} / \mathrm{kg})$ or PBS.

b Number of mice per treatment group: A/J, Oil/PBS and Oil/ $/ \mathrm{V}_{2} \mathrm{O}_{5}(\mathrm{n}=3), \mathrm{MCA} / \mathrm{PBS}(\mathrm{n}=4), \mathrm{MCA} / \mathrm{N}_{2} \mathrm{O}_{5}(\mathrm{n}=15) ; \mathrm{BALB}, \mathrm{Oil} / \mathrm{PBS}$ and Oil/ $\mathrm{V}_{2} \mathrm{O}_{5}(\mathrm{n}$

$=3-5), M C A / P B S(n=8), M C A / V_{2} O_{5}(n=13) ; B 6$, Oil/PBS and Oil/ $V_{2} O_{5}(n=3-8), M C A / P B S(n=7), M C A / V_{2} O_{5}(n=12)$.

c No tumors were detected in $\mathrm{B} 6$ mice in any of the experimental groups examined (data not shown).

d A significant strain effect was detected for tumor size $(\mathrm{mm})$ between $\mathrm{A} / \mathrm{J}(0.72 \pm 0.012)$ and BALB mice $(0.59 \pm 0.054)(P<0.05)$.

* Significantly different from strain-matched MCA-treated/PBS controls $(P<0.05)$.

\# Significantly different than treatment-matched BALB mice $(A / J$ vs BALB, $P<0.05)$. 
ily as a lung tumor promoter in both $\mathrm{A} / \mathrm{J}$ and BALB mice following a low dose of MCA given as an initiating agent (Table 1; $P<0.05$ ). For both strains, tumor multiplicity was higher in $\mathrm{V}_{2} \mathrm{O}_{5}$-treated mice compared to MCAtreated, PBS controls $(P<0.05)$. Additionally, a significant difference in tumor multiplicity and size was observed between BALB and $\mathrm{A} / \mathrm{J}$ in the MCA group (Table 1). In the absence of MCA, $\mathrm{V}_{2} \mathrm{O}_{5}$ exposure alone was not sufficient to initiate tumorigenesis. No tumors were detected in B6 mice in any of the experimental groups examined (data not shown). In $\mathrm{A} / \mathrm{J}$ and BALB mice, tumors were further evaluated by histopathological analyses in a subset of animals. A majority of the tumors were found to be solid adenomas $(80 \%)$ and the remaining papillary $(20 \%)$, consistent with previous studies using MCA [48].

\section{$A / J$ and BALB mice are more susceptible to $\mathrm{V}_{2} \mathrm{O}_{5}$-induced pulmonary hyperpermeability and inflammation than $\mathrm{B} 6$ mice}

To determine whether chronic inflammation was associated with tumor promotion, we evaluated strain differences in BALF cellularity and protein content up to 21 days following the final $\mathrm{V}_{2} \mathrm{O}_{5}$ dose (Fig. 2). In general, susceptibility to pulmonary inflammation and hyperpermeability proceeded in the order $\mathrm{A} / \mathrm{J}>\mathrm{BALB}>\mathrm{B} 6$ mice (Fig. 2A-2E). BALF protein content increased significantly in all strains at $6 \mathrm{hr}$ following $\mathrm{V}_{2} \mathrm{O}_{5}$ exposure and returned to baseline by 21 days (Fig. $2 \mathrm{~A}, P<0.05$ ). The peak protein response was at $6 \mathrm{hr}$ in BALB and B6 mice compared to 1 day in the $A / J$ strain. Furthermore, protein levels in A/J mice remained significantly elevated above other strains at 3 days.

The effects of $\mathrm{V}_{2} \mathrm{O}_{5}$ on BALF cellularity are depicted in Fig. 2B-2E. As shown, the extent and duration of the inflammatory response was significantly greater in $\mathrm{A} / \mathrm{J}$ mice at all time points examined $(P<0.05$; Fig. $2 \mathrm{~B})$. The most striking difference between strains was observed for PMNs, which was highest at 1 day (Fig. 2D). A/J mice exhibited a $\sim 150$-fold increase in the number of PMNs infiltrating the lung representing $36 \%$ of the total cells recovered compared to a 43 -fold increase in BALB (34\%) and only a 16-fold increase ( 7\%) in B6 mice. By 21 days, inflammation completely resolved in $\mathrm{B} 6$ mice, but the total number of cells, primarily macrophages and some lymphocytes, remained elevated in $\mathrm{A} / \mathrm{J}$ and to a lesser degree in BALB mice $(P<0.05)$.

The BALF results were further confirmed using histological staining with an anti-PMN marker in lung sections from the most (A/J) and least sensitive (B6) strains 1 day following the final $\mathrm{V}_{2} \mathrm{O}_{5}$ dose (Figure 3). Figures 3A-D demonstrate higher PMN influx in the A/J strain compared to both B6 mice and PBS controls. Positive staining for PMNs was observed primarily around the bronchioles and in close proximity to the alveolar epithelium, although staining was also seen surrounding larger airways. Increased cellularity of the bronchiolar and alveolar epithelium, indicative of epithelial cell proliferation, was also observed in $\mathrm{A} / \mathrm{J}$, but not $\mathrm{B} 6$ mice when compared to PBS controls.

In a separate study, we assessed the inflammatory cell profile in the most sensitive strain (A/J) 21 days following the last $\mathrm{V}_{2} \mathrm{O}_{5}$ dose to determine any synergistic effect of MCA on inflammation (Table 2). For all phenotypes examined (BALF total protein, and total cells including macrophages, lymphocytes, and PMNs), there were significant increases in mice treated with $\mathrm{V}_{2} \mathrm{O}_{5}$ compared to PBS controls. There were no significant differences between animals treated with MCA or with oil in any of the groups (Table 2), suggesting that $\mathrm{V}_{2} \mathrm{O}_{5}$ was primarily driving the inflammatory response. The total cell numbers and macrophages in this study were higher compared to Protocol 2 at this time point (21 days), due to the extra weekly dose of $\mathrm{V}_{2} \mathrm{O}_{5}$ used to maximize promotion.

To further confirm that strain differences in tumor promotion were not due to differences in inflammatory responses to $\mathrm{MCA}$, an additional control experiment was conducted (Fig. 1C, Protocol 3). MCA or oil was administered to mice followed by 4 weekly doses of PBS and differences in BALF protein content and cellularity were measured at $6 \mathrm{hr}$ and 1 day following the last aspiration (Additional file 1, Table S1). BALB mice exhibited a significant increase in protein levels compared to the other strains, similar to that observed in Fig. 2. Both BALB and A/J mice also had higher PMNs compared to B6 mice, however no additional effects of MCA on inflammatory cell types were observed within strains (Additional file 1, Table S1). Thus, these results provide further evidence that strain susceptibility to inflammation induced by $\mathrm{V}_{2} \mathrm{O}_{5}$ and not to MCA is more strongly associated with lung tumor promotion in our model.

\section{Strain differences in $\mathrm{V}_{2} \mathrm{O}_{5}$-induced inflammatory chemokine (KC, MIP-2, MCP-1) expression}

Differential strain responses were detected for the chemokines KC and MCP-1 (Fig. 4A, C), with higher levels observed in both $\mathrm{A} / \mathrm{J}$ and BALB compared to $\mathrm{B} 6$ mice. $\mathrm{KC}$ increased 3-fold and MCP-1 by 2.5 -fold at $6 \mathrm{hr}$ and remained elevated in $\mathrm{A} / \mathrm{J}$ mice at 1 day following the last $\mathrm{V}_{2} \mathrm{O}_{5}$ dose (Fig. 4A, C; $P<0.05$ ). In BALB mice, chemokine levels increased to a similar extent at $6 \mathrm{hr}$, but levels declined sharply by 1 day. Comparably, only modest increases ( 1.5-fold) were seen in B6 mice. Strain responses were more variable and less pronounced for MIP-2 (Fig. 4B). MIP-2 increased significantly in all strains at $6 \mathrm{hr}$, with overall changes of 1.5-fold in A/J, 1.1fold in BALB, and 1.2-fold in B6 mice. 

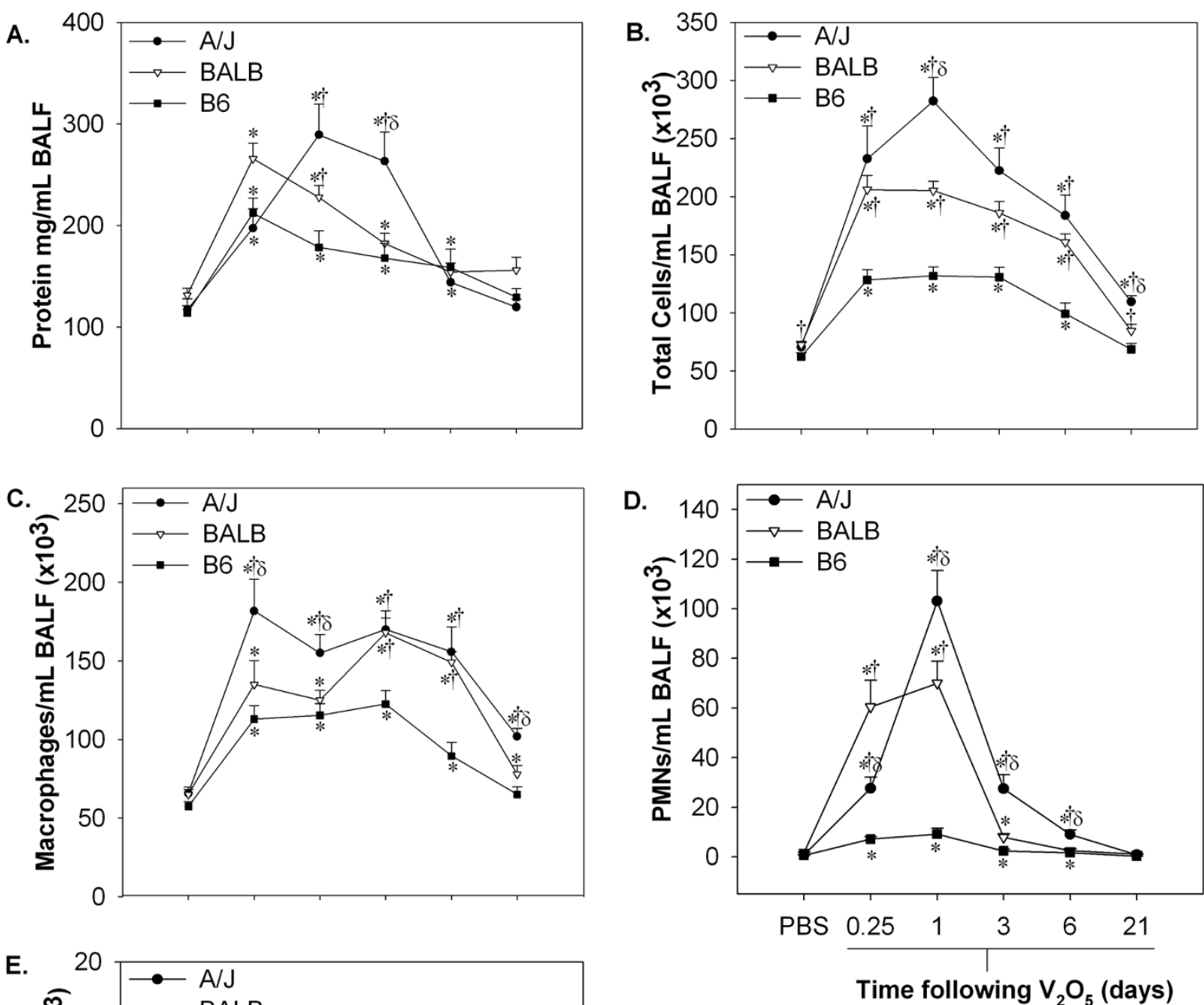

E.

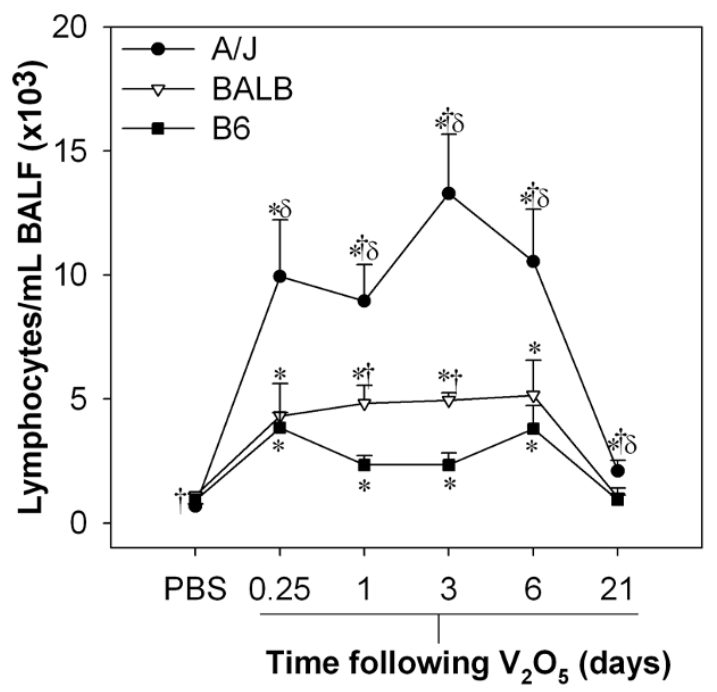

Time following $\mathrm{V}_{2} \mathrm{O}_{5}$ (days)

Figure $2 \mathrm{~A} / \mathrm{J}$ and $\mathrm{BALB}$ are susceptible to pulmonary inflammation and hyperpermeability in response to sub-chronic $\mathrm{V}_{2} \mathrm{O}_{5} \cdot \mathrm{A} / J, \mathrm{BALB}, \mathrm{and}$ $\mathrm{B} 6$ mice were exposed to 4 weekly doses of $\mathrm{V}_{2} \mathrm{O}_{5}(4 \mathrm{mg} / \mathrm{kg}$ ) by aspiration and sacrificed $0.25,1,3,6,21$ days after the last exposure. A.) Bronchoalveolar lavage (BALF) protein $(\mu \mathrm{g} / \mathrm{mL}$ ) and B.) total cells, C.) macrophages, D.) PMNs, and (E) lymphocytes per $\mathrm{mL}$ of BALF. Data represent the mean \pm SEM ( $\mathrm{n}$ $=5-15$ animals/group). ${ }^{*}$, significantly different than strain-matched PBS controls. + , significantly different than time-matched B6 mice. $\delta$, significantly different than time-matched BALB mice $(P<0.05)$. 


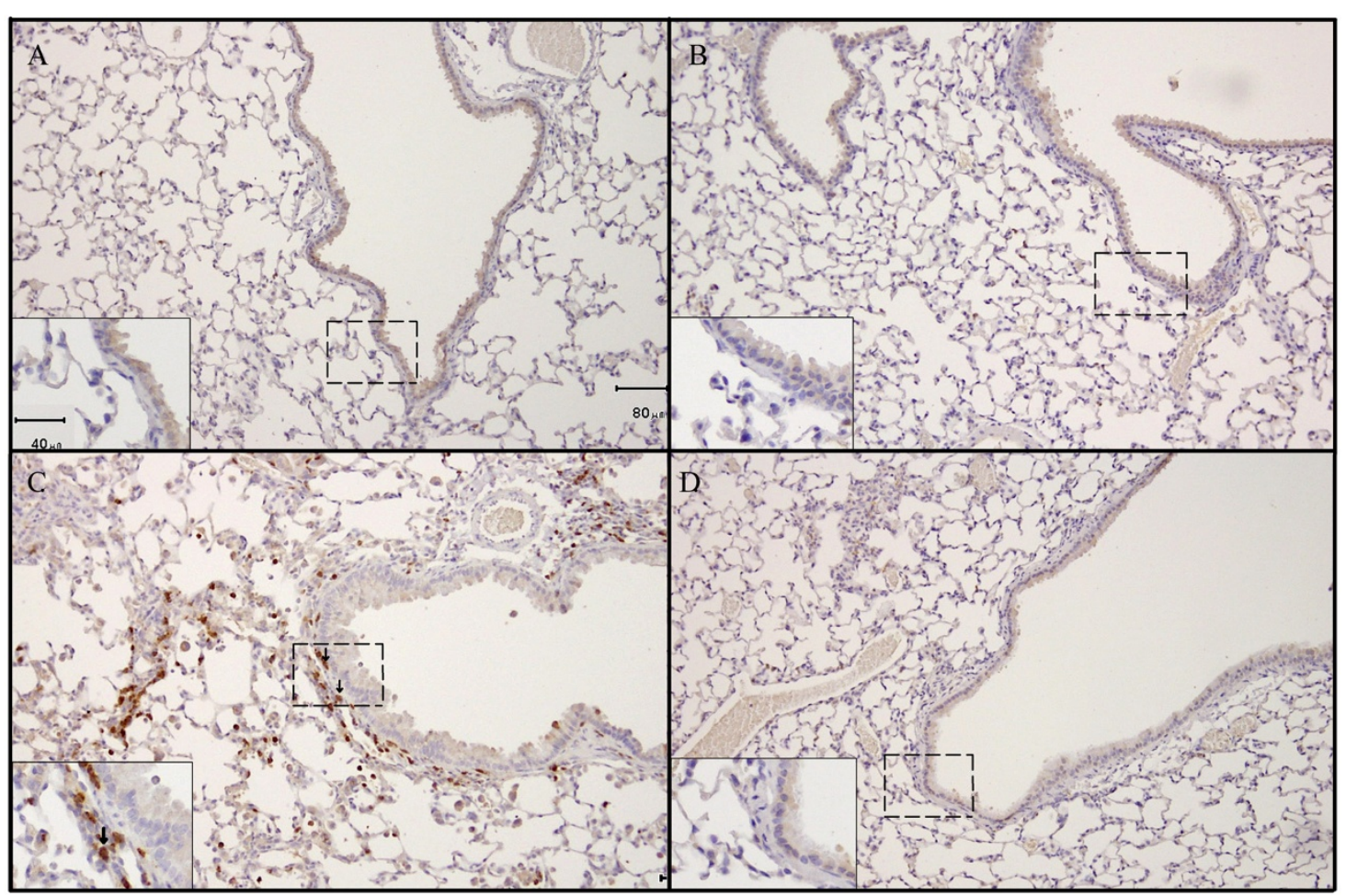

Figure 3 Neutrophil influx into lungs of $\mathbf{A} / \mathbf{J}$ mice in response to sub-chronic $\mathbf{V}_{\mathbf{2}} \mathbf{O}_{\mathbf{5}}$. Neutrophils were detected by immunohistochemical staining using an anti-mouse neutrophil antibody in formalin fixed lung sections. A.) PBS-treated A/J mouse; B.) PBS-treated B6 mouse, C.) $V_{2} \mathrm{O}_{5}$-treated A/J mouse, 1 day; D.) $V_{2} \mathrm{O}_{5}$-treated $\mathrm{B} 6$ mouse, 1 day. Original magnifications $\times 100$, insets $\times 200$. Arrows indicate areas with positive staining for neutrophils (red-brown in color), dashed boxes indicate areas magnified within the insets.

\section{$\mathrm{A} / \mathrm{J}$ mice have higher transcriptional activity of $\mathrm{NFKB}$ and AP-1 than $\mathrm{B} 6$ mice following $\mathrm{V}_{2} \mathrm{O}_{5}$}

Nuclear transcription factor activity and MAPK signaling (see below) were evaluated in the most sensitive (A/J) and resistant (B6) strains (Fig. 5). Sub-chronic administration of $\mathrm{V}_{2} \mathrm{O}_{5}$ resulted in higher nuclear NFKB binding activity in $\mathrm{A} / \mathrm{J}$ mice at both $6 \mathrm{hr}$ and 1 day, with binding activity at 1 day significantly greater than all other groups (Fig. 5A; $P<0.05)$. No corresponding changes were observed in B6 mice at the time points assessed (Fig. 5A). Nuclear activ- ity for the AP-1 transcription factor, c-Fos increased significantly in both strains, but more so at $6 \mathrm{hr}$ in $\mathrm{A} / \mathrm{J}$ compared to B6 mice (Fig. 5B; $P<0.05$ ).

\section{$\mathrm{V}_{2} \mathrm{O}_{5}$ activates the MAPKs ERK1/2 and p38 in pulmonary tissue}

Strain differences in MAPK signaling were assessed in whole lung homogenates (Fig. 6). Compared to PBS controls, a significant increase in phosphorylation of $\mathrm{p} 38$ and ERK1/2 were observed in both A/J and B6 mice $6 \mathrm{hr}$ fol-

Table 2: Pulmonary inflammation and hyperpermeability in $A / J$ mice treated with either corn oil or MCA $(10 \mu g / g)$ and then aspirated with 5 weekly doses of $\mathrm{V}_{2} \mathrm{O}_{5}(\mathbf{m g} / \mathrm{kg})$ or PBS.a

\begin{tabular}{lccccc}
\hline Treatment & Protein $(\boldsymbol{\mu g} / \mathbf{m L})$ & Total Cells $\left(\times \mathbf{1 0}^{3}\right)$ & $\begin{array}{c}\text { Macrophages } \\
\left(\times 10^{3}\right)\end{array}$ & $\begin{array}{c}\text { Lymphocytes } \\
\left(\times \mathbf{1 0}^{3}\right)\end{array}$ & $\begin{array}{c}\text { PMNs } \\
\left(\times \mathbf{1 0}^{3}\right)\end{array}$ \\
\hline $\mathrm{Oil} / \mathrm{PBS}$ & $129 \pm 4.3$ & $79.7 \pm 8.8$ & $73.7 \pm 7.9$ & $0.572 \pm 0.12$ & $0.422 \pm 0.12$ \\
$\mathrm{Oil} / \mathrm{V}_{2} \mathrm{O}_{5}$ & $166 \pm 4.0^{*}$ & $156 \pm 17^{*}$ & $147 \pm 18^{*}$ & $4.14 \pm 0.65^{*}$ & $0.737 \pm 0.23^{*}$ \\
$\mathrm{MCA} / \mathrm{PBS}$ & $132 \pm 15$ & $83.1 \pm 11$ & $76.3 \pm 11$ & $0.109 \pm 0.07$ & $0.271 \pm 0.073$ \\
$\mathrm{MCA} / \mathrm{N}_{2} \mathrm{O}_{5}$ & $198 \pm 25^{*}$ & $161 \pm 16^{*}$ & $149 \pm 18^{*}$ & $6.01 \pm 0.81^{*}$ & $1.47 \pm 0.38^{*}$ \\
\hline
\end{tabular}

${ }^{\mathrm{a}} \mathrm{A} / \mathrm{J}$ mice were treated with corn oil (control) or MCA $(10 \mu \mathrm{g} / \mathrm{g})$ and then aspirated with 5 weekly doses of either PBS or $\mathrm{V}_{2} \mathrm{O}_{5}(4 \mathrm{mg} / \mathrm{kg})$. Animals were sacrificed 21 days after the last aspiration. Protein $(\mu \mathrm{g} / \mathrm{mL})$ concentration and inflammation were measured in bronchoalveolar lavage fluid (BALF) and data are expressed as cells $\left(\times 10^{3}\right)$ per $\mathrm{mL}$ of BALF. Data represent the mean \pm SEM ( $\mathrm{n}=4-7$ animals/group).

* Significantly different from PBS exposed animals $(P<0.05)$. 

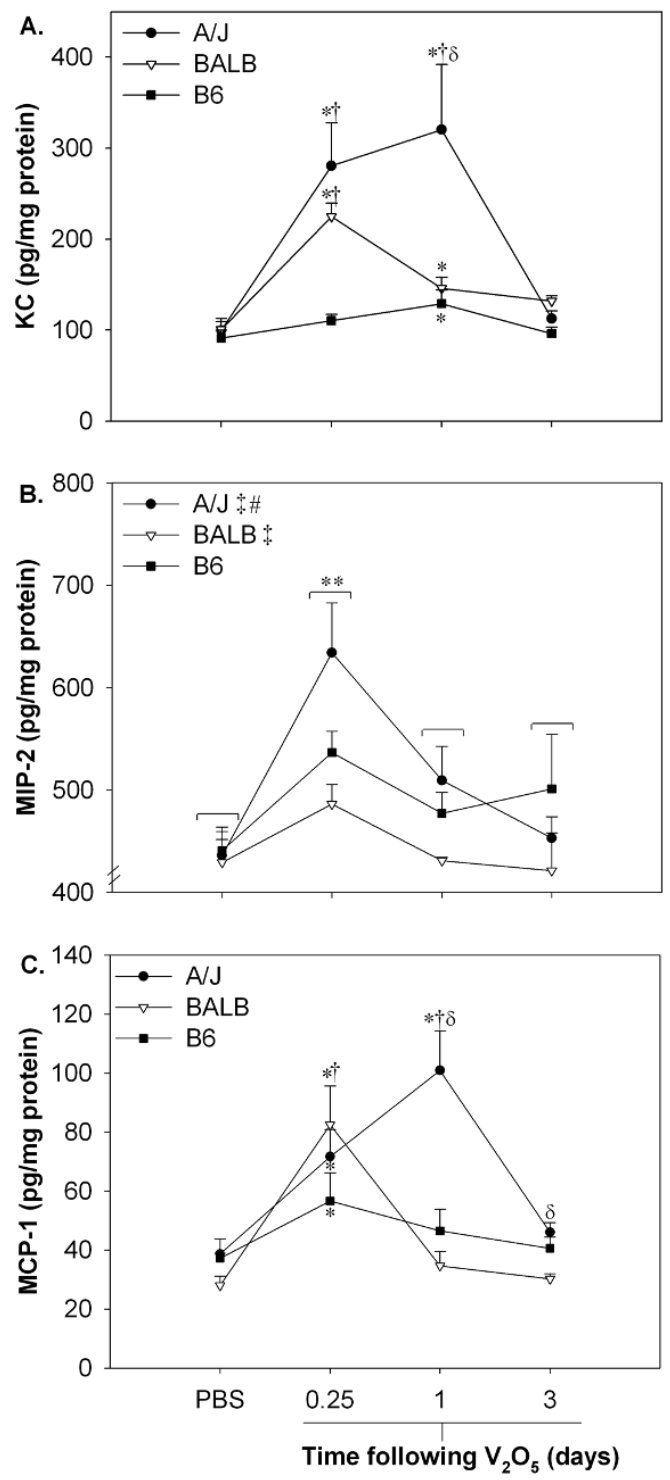

Figure 4 The chemokines KC and MCP-1 are elevated in $\mathrm{A} / \mathrm{J}$ and BALB mice following $\mathrm{V}_{2} \mathrm{O}_{5}$ treatment. A.) $\mathrm{KC}$, keratinocyte chemoattractant, B.) MIP-2, macrophage inflammatory protein-2, C.) MCP-1, monocyte chemoattractant protein-1 levels were determined in lung homogenates (25-50 $\mu \mathrm{g}$ protein) by ELISA. Values are presented as means \pm SEM from two independent assays. *, significantly different than strain-matched PBS controls. †, significantly different than timematched B6 mice. $\delta$, significantly different than time-matched BALB mice. ${ }^{* *}$, significant treatment effect $\left(6 \mathrm{hr}_{2} \mathrm{O}_{5}\right.$ vs PBS control). $\neq$, significant strain effect (A/J vs B6, BALB vs B6). \#, significant strain effect (A/J vs BALB) $(P<0.05)$.

lowing $\mathrm{V}_{2} \mathrm{O}_{5}$ treatment. By one day, phospho-p38 returned to basal levels in both strains (Fig. 6B), whereas phospho-ERK1/2 remained elevated in A/J mice (Fig. 6A; $P<0.05)$. No significant changes in JNK1/2 were observed between or within strains at any of the time points examined (Fig. 6C). Because MCA has been shown to induce intracellular oxidant levels [46], we also measured the MAPKs ERK1/2 and p38 in B6 and A/J mice from Protocol 3 (Additional file 2, Fig. 1S). There was a slight but non-significant increase in phospho-p38 in MCA-treated B6 mice $6 \mathrm{hr}$ following the last PBS aspiration, however no significant differences between strains were observed for either MAPK examined (Additional file 2, Fig. 1S).

\section{Discussion}

Chronic inflammation is a risk factor for several cancer types [49]. Asthmatics and individuals with COPD are at an elevated lifetime risk for developing lung cancer [50]. The importance of inflammation in augmenting pulmonary carcinogenesis is further supported by a wide range of pharmaceutical compounds that inhibit neoplastic development [51] as well as evidence from transgenic mouse models [52,53]. Because tumor promotion involves changes in gene expression, most likely epigenetic in nature, and is the only reversible stage of carcinogenesis, studying promoters may identify additional pathways to target for preventive strategies against human lung cancer.

In the current investigation, we provide evidence that $\mathrm{V}_{2} \mathrm{O}_{5}$ functions as an in vivo tumor promoter among differentially susceptible inbred strains of mice. Using a twostage model of carcinogenesis, a significant increase in tumor multiplicity was observed in both A/J $(10.3 \pm 0.9$ tumors/mouse) and BALB $(2.2 \pm 0.36)$ mice exposed to the carcinogen MCA followed by 5 weekly aspirations of $\mathrm{V}_{2} \mathrm{O}_{5}$. The effect of $\mathrm{V}_{2} \mathrm{O}_{5}$ was limited to tumor promotion, as no significant increase in tumor numbers were observed in animals exposed to $\mathrm{V}_{2} \mathrm{O}_{5}$ alone. Susceptibility to promotion paralleled relative strain sensitivity to $\mathrm{V}_{2} \mathrm{O}_{5}$-induced inflammation: $\mathrm{A} / \mathrm{J}$ mice were most sensitive and BALB were intermediate. $\mathrm{B} 6$ mice were found to be most resistant to $\mathrm{V}_{2} \mathrm{O}_{5}$-induced inflammation, however were used as a control since they are not initiated by the low dose of MCA administered in this study [37].

Differences between the two susceptible strains of mice (A/J and BALB) are not unusual based on past genome mapping studies demonstrating distinct genes responsible for tumorigenesis in these specific strains [54,55]. While both strains are susceptible to lung tumor development, differences in sensitivity between these two strains has been linked to quantitative trait loci containing both tumor suppressor genes as well as inflammatory mediators, such as myeloperoxidase ( $\mathrm{Mpo})$, colony stimulating factor (Csf) 3, CC chemokine receptor (Ccr10), and Ccl2 (Mcp-1) $[54,55]$. Although MCA was used as an initiating agent in this study, additional control experiments fur- 


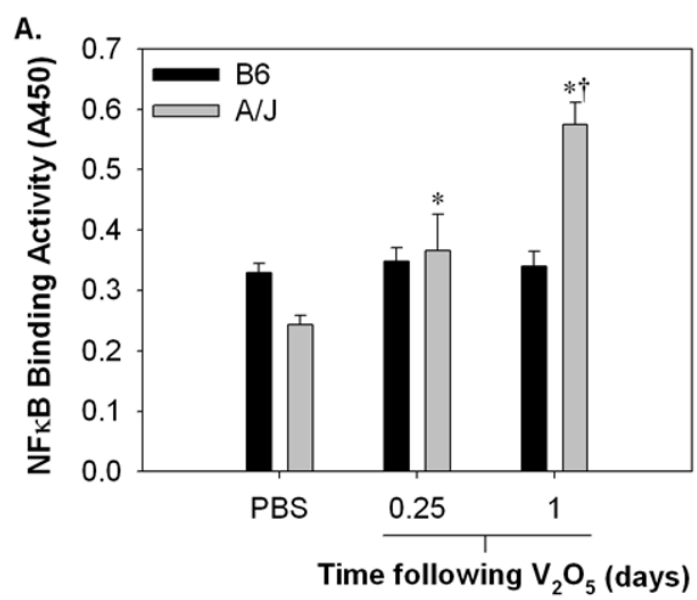

B.

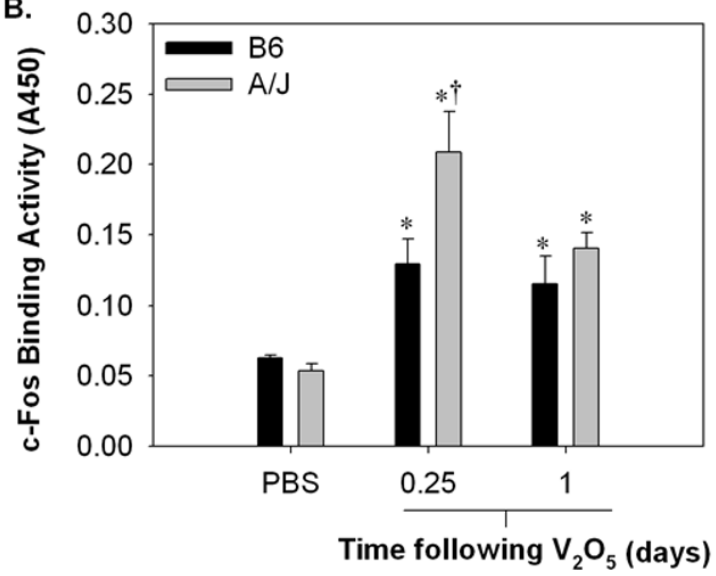

Figure $5 \mathrm{NFKB}$ and c-Fos are differentially regulated in $\mathbf{A} / \mathbf{J}$ and $\mathbf{B} 6$ mice following $\mathbf{V}_{\mathbf{2}} \mathrm{O}_{\mathbf{5}}$ instillation. Nuclear binding activity for $A$.) $N F K B$ and $B$.) c-Fos were determined by transcription factor ELISA TransAM kits in nuclear protein extracts $(8 \mu \mathrm{g})$ prepared from the lungs of $\mathrm{chronic}_{2} \mathrm{~V}_{5}$ treated mice ( $n=3-6 /$ group). * , significantly different than strain-matched PBS controls $(P<0.05)$. + , significantly different than time-matched B6 mice $(P<$ 0.05).

ther demonstrated that carcinogen treatment alone did not influence inflammatory indices between strains. Because significant strain responses were observed only in response to $\mathrm{V}_{2} \mathrm{O}_{5}$, our findings suggest that that genetic (host) factors contributing to $\mathrm{V}_{2} \mathrm{O}_{5}$-induced pulmonary inflammation are also strongly associated to lung tumor promotion.

Vanadium is thought to mediate pulmonary inflammation through generation of multiple reactive oxygen species $\left(\mathrm{O}_{2}^{-}, \mathrm{H}_{2} \mathrm{O}_{2}\right.$, and. $\left.\mathrm{OH}\right)$ in target cells [56-58]. Production of ROS is associated with phosphorylation of EGF-R and activation of MAPK signaling [57,59-63] as well as the transcription factors NFKB [59,63], AP-1 $[59,64]$, and STAT-1 [65]. Furthermore, vanadium is known to be a phosphatase inhibitor [66] and likely prolongs phosphorylation and signaling along ROS-sensitive pathways. These events, in turn can influence the synthesis and release of pro-inflammatory cytokines and chemokines mediating acute lung injury $[29,65,67,68]$. Pretreatment of human bronchial epithelial cells with metal chelators and/or free radical scavengers reduces vanadium-generated ROS, MAPK activation, as well as release of chemokines, further supporting a role for oxidative stress in vanadium-induced inflammation [62].

In our study, differential strain induction of chemokines and upstream signaling molecules in response to $\mathrm{V}_{2} \mathrm{O}_{5}$ correlated to the extent and duration of inflammatory cells recovered in pulmonary tissue. MIP-2 and KC are principle neutrophil chemoattractants in rodent models, homologous to IL-8 in humans [69], whereas
MCP-1 induces monocyte and lymphocyte chemotaxis and migration [70]. We observed moderate, although significant induction of MIP-2 in all strains at $6 \mathrm{hr}$ following vanadium exposure, which likely involved initial PMN influx. However, strain differences in the peak PMN response were more closely associated with pulmonary levels of KC. MCP-1 was highly induced in A/J and BALB mice and expression coincided with the influx of both monocytes and lymphocytes into pulmonary tissue. The transcription factors $\mathrm{NF} \kappa \mathrm{B}$ and c-Fos as well as the MAPK pERK1/2 were also found to be differentially regulated in the sensitive (A/J) and resistant (B6) mice and corresponded to both altered chemokine induction and BALF cellularity.

The microenvironment is becoming increasingly recognized as actively contributing to the tumorigenic process. Evidence suggests that PMNs and macrophages appear to be involved in tumor development through multiple mechanisms, including more direct, such as induction of DNA damage and regulation of cell cycle [71], as well as indirect mechanisms, such as promotion of angiogenesis by cytokines and chemokines and suppression of adaptive immune responses [71,72]. Local production of cytokines and chemokines may also stimulate expansion of initiated cells by influencing cell proliferation and apoptotic pathways [14]. Several signaling molecules altered by $\mathrm{V}_{2} \mathrm{O}_{5}$ in this study have been implicated in lung cancer development. For example, IL-8 has been reported to serve as an autocrine growth factor in lung cancer cell lines [73,74] and both IL- 8 and MCP-1 are elevated in bronchiolar epi- 


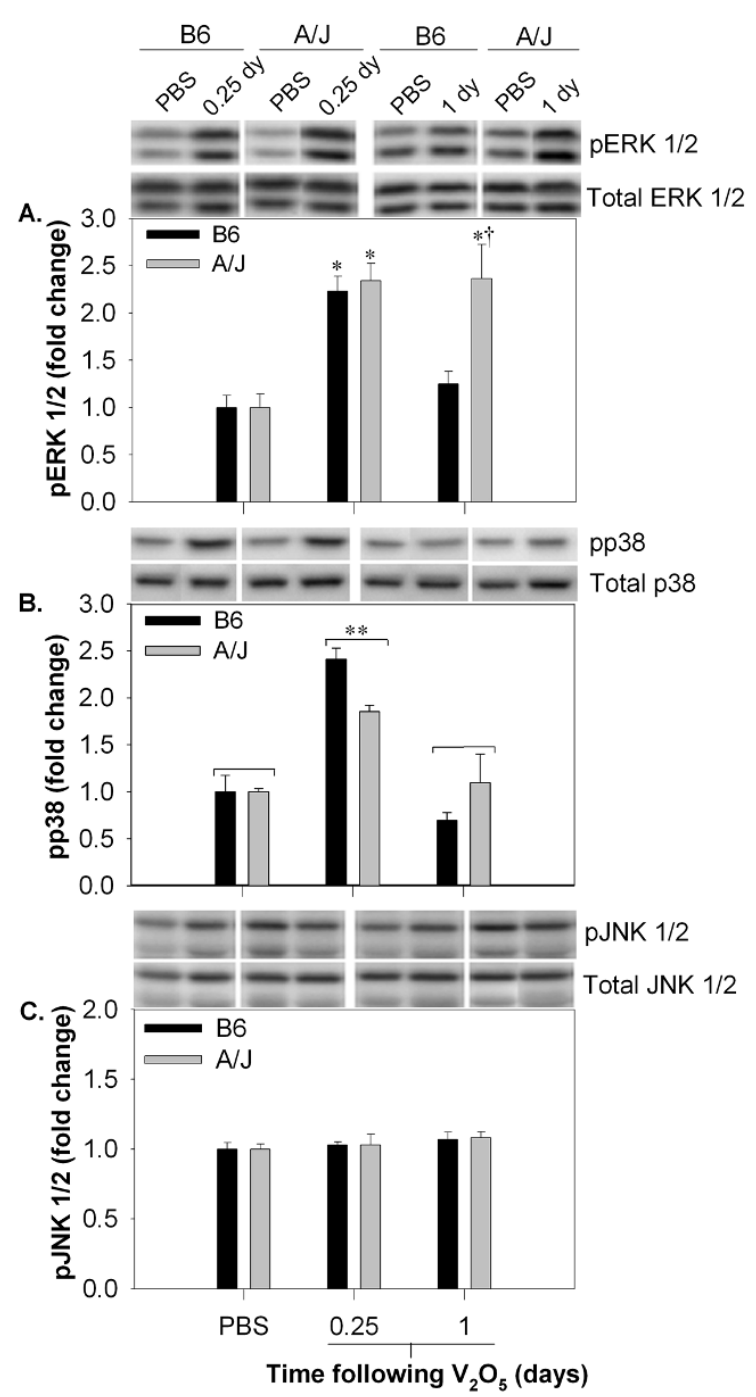

Figure 6 ERK $1 / 2$ is differentially activated in $A / J$ compared to $B 6$ mice following sub-chronic $\mathrm{V}_{2} \mathrm{O}_{5}$ instillation. Homogenates were prepared from the right lungs of mice A.) $6 \mathrm{hr}$ and B.) 1 day after the last $\mathrm{V}_{2} \mathrm{O}_{5}$ exposure ( $n=3-5 /$ group). Phosphorylated and total levels of MAPK in lung homogenates were analyzed from $100 \mu \mathrm{g}$ protein by Western blotting. Representative images and mean band intensities are representative of 2-3 independent experiments. *, significantly different than strain-matched PBS controls $(P<0.05) .{ }^{* *}$, significant main effect of time. $t$, significantly different than time-matched B6 mice $(P<$ 0.05)

thelium from patients with COPD [75,76] and non-small cell lung cancer (NSCLC) [77]. In mouse models, neutralization of CXCR2, the principle receptor for $\mathrm{KC}$ and MIP-2 reduces PMN infiltration [78] as well as tumor growth and angiogenesis, suggesting a role in tumor progression $[53,79,80]$. Constitutive activation of pERK1/2 $[81,82]$ and the transcription factors NFkB $[83]$ and c-Fos [84] have well known effects on cell cycle regulation.
Additional evidence for ERK1/2 in pulmonary tumorigenesis was recently demonstrated in transgenic mice overexpressing mutant $B$-raf and $K$-ras. Pharmacological inhibition of pERK1/2 resulted in tumor regression by inhibiting cell proliferation and restoring apoptosis [81]. Constitutive activation of ERK1/2 was also observed in $\mathrm{V}_{2} \mathrm{O}_{5}$-induced mouse carcinomas from the NTP study containing both $\mathrm{K}$-ras mutations and loss of heterozygosity [85], which supports findings in this model and suggests involvement of ERK1/2 as one pathway driving tumor promotion by $\mathrm{V}_{2} \mathrm{O}_{5}$.

\section{Conclusions}

Our study provides evidence that $\mathrm{V}_{2} \mathrm{O}_{5}$ functions as an in vivo tumor promoter and suggests that susceptibility to $\mathrm{V}_{2} \mathrm{O}_{5}$-induced inflammation and tumor promotion is influenced by genetic background. Tumor promotion in our model was associated with a robust inflammatory response involving induction of multiple chemokines, the transcription factors $\mathrm{NF \kappa B}$ and c-Fos, as well as sustained activation of ERK1/2 in susceptible mice. These findings suggest that activation of oxidative stress-mediated signaling events may be one mechanism contributing to increased lung cancer risk by PM. A limitation in the current study was that the dose of $\mathrm{V}_{2} \mathrm{O}_{5}$ utilized was significantly higher than either occupational or ambient exposure levels, and was not meant to be directly used for risk assessment. It should be noted, however, that in the NTP study, a significant increase in pulmonary tumors was also reported after 2 years in $\mathrm{B} 6 \mathrm{C} 3 \mathrm{~F} 1$ mice, a resistant strain, at more relevant occupational levels of $\mathrm{V}_{2} \mathrm{O}_{5}$. Although we found that $\mathrm{V}_{2} \mathrm{O}_{5}$ alone did not initiate tumorigenesis, our findings highlight that repeated exposures to inflammatory stimuli augments pulmonary carcinogenesis in susceptible strains. Additional studies examining genetic differences in antioxidant enzyme levels and adenoma susceptibility genes potentially contributing to tumor promotion by $\mathrm{V}_{2} \mathrm{O}_{5}$ as well as to other PM constituents warrant further investigation.

\section{Additional material}

Additional file 1 Table S1. Pulmonary inflammation and hyperpermeability in B6, BALB, and A/J mice treated with corn oil or MCA $(10 \mu \mathrm{g} /$ g) and then aspirated with 4 weekly doses of PBS.

Additional file 2 Figure $S 1$. The MAPKs ERK $1 / 2$ and p38 are not significantly altered between $\mathrm{B} 6$ or $\mathrm{A} / \mathrm{J}$ mice treated with the carcinogen MCA $(10 \mu \mathrm{g} / \mathrm{g})$ and then aspirated with 4 weekly doses of PBS. Homogenates were prepared from the right lungs of mice treated with either MCA or oil and then 4 weekly aspirations of PBS ( $n=3-5 /$ group). Phosphorylated and total levels of MAPK in lung homogenates were analyzed from $75 \mu \mathrm{g}$ protein by Western blotting. Representative images and mean band intensities are representative of 2-3 independent experiments. No significant differences were observed for either of the MAPK tested $(P>0.05)$. 


\section{Abbreviations}

ANOVA: Analysis of variance; AP-1: Activator protein-1; BALB: BALBC/J; B6: C57BL/6J; BALF: Bronchoalveolar lavage fluid; COPD: chronic obstructive pulmonary disease; ELISA: Enzyme-linked immunosorbent assay; ERK: Extracellular-signal related kinase; KC: Keratinocyte-derived chemokine; MAPK: Mitogenactivated protein kinase; MCP-1: Monocyte chemoattractant protein-1; MIP-2: Macrophage inflammatory protein-2; NSCLC: non small cell lung cancer; NFKB: Nuclear factor-kappa B; JNK: c-Jun N-terminal kinase; PBS: Phosphate buffered saline; PM: Particulate matter; RNS: Reactive nitrogen species; ROS: Reactive oxygen species; ROFA: Residual oil fly ash; TBS: Tris buffered saline; TBST: Tris buffered saline with Tween-20; $\mathrm{V}_{2} \mathrm{O}_{5}$ : Vanadium pentoxide.

\section{Competing interests}

The authors declare that they have no competing interests.

\section{Authors' contributions}

EAR performed $\mathrm{V}_{2} \mathrm{O}_{5}$ exposures, BAL analysis, and all experimental procedures (immunohistochemistry, ELISAs, immunoblots, transcription factor assays), as well as drafted the manuscript. DMW assisted in experimental design. AKB conceived of the study design and methodology utilized, assisted in $\mathrm{V}_{2} \mathrm{O}_{5}$ exposures and euthanasia, enumerated pulmonary tumors, and helped to draft the manuscript. All authors read and approved the final manuscript.

\section{Acknowledgements}

The authors would like to thank the Department of Pathobiology and Diagnostic Investigation and the Center for Integrative Toxicology at Michigan State University for funding this project.

\section{Author Details}

'Department of Pathobiology and Diagnostic Investigation and Center for Integrative Toxicology, Michigan State University, East Lansing, MI, 48824, USA and 2 Department of Physiology, Brody School of Medicine, East Carolina University, Greenville, North Carolina, 27834, USA

Received: 25 November 2009 Accepted: 12 April 2010 Published: 12 April 2010

\section{References}

1. Ferlay J, Bray F, Pisani P, Parkin DM: GLOBOCAN 2002: Cancer incidence, mortality, and prevalence worldwide Lyon, France: IARC Press; 2004

2. Jemal A, Siegel R, Ward E, Murray T, Xu J, Thun MJ: Cancer statistics, 2007. CA Cancer J Clin 2007, 57:43-66.

3. Thun MJ, Henley SJ, Burns D, Jemal A, Shanks TG, Calle EE: Lung cancer death rates in lifelong nonsmokers. J Nat/ Cancer Inst 2006, 98:691-699.

4. Siemiatycki J, Richardson L, Straif K, Latreille B, Lakhani R, Campbell S, Rousseau MC, Boffetta P: Listing occupational carcinogens. Environ Health Perspect 2004, 112:1447-1459.

5. Barbone F, Bovenzi M, Cavallieri F, Stanta G: Air-Pollution and LungCancer in Trieste, Italy. American Journal of Epidemiology 1995, 141:1161-1169.

6. Dockery DW, Pope CA III, Xu X, Spengler JD, Ware JH, Fay ME, Ferris BG Jr, Speizer FE: An association between air pollution and mortality in six U.S. cities. NEngl J Med 1993, 329:1753-1759.

7. Pope CA, Burnett RT, Thun MJ, Calle EE, Krewski D, Ito K, Thurston GD: Lung cancer, cardiopulmonary mortality, and long-term exposure to fine particulate air pollution. Jama 2002, 287:1132-1141.

8. Pope CA, Namboodiri MM, Dockery DW, Evans JS, Speizer FE, Heath CW: Particulate air pollution as a predictor of mortality in a prospective study of U.S. adults. Am J Respir Crit Care Med 1995, 151:669-674.

9. U.S.EPA: Air Quality Criteria for Particulate Matter (Final Report, Oct 2004) Washington, DC, USA: U.S. Environmental Protection Agency; 2004.

10. WHO: Health Aspects of Air Pollution with Particulate Matter, Ozone and Nitrogen Dioxide Bonn, Germany: World Health Organization (WHO); 2003.

11. Lippmann M, Yeates DB, Albert RE: Deposition, retention, and clearance of inhaled particles. Br J Ind Med 1980, 37:337-362.

12. Cohen AJ, Ross Anderson H, Ostro B, Pandey KD, Krzyzanowski M, Kunzli N, Gutschmidt K, Pope A, Romieu I, Samet JM, Smith K: The global burden of disease due to outdoor air pollution. J Toxicol Environ Health A 2005, 68:1301-1307.

13. Galaris $D$, Evangelou A: The role of oxidative stress in mechanisms of metal-induced carcinogenesis. Crit Rev Oncol Hematol 2002, 42:93-103.
14. Knaapen AM, Borm PJ, Albrecht C, Schins RP: Inhaled particles and lung cancer. Part A: Mechanisms. Int J Cancer 2004, 109:799-809.

15. Bonner JC: Lung fibrotic responses to particle exposure. Toxicol Pathol 2007, 35:148-153.

16. Costa DL, Dreher KL: Bioavailable transition metals in particulate matter mediate cardiopulmonary injury in healthy and compromised animal models. Environ Health Perspect 1997, 105(Suppl 5):1053-1060.

17. Dreher KL, Jaskot RH, Lehmann JR, Richards JH, McGee JK, Ghio AJ, Costa DL: Soluble transition metals mediate residual oil fly ash induced acute lung injury. J Toxicol Environ Health 1997, 50:285-305.

18. Kadiiska MB, Mason RP, Dreher KL, Costa DL, Ghio AJ: In vivo evidence of free radical formation in the rat lung after exposure to an emission source air pollution particle. Chemical Research in Toxicology 1997, 10:1104-1108

19. Saldiva PH, Clarke RW, Coull BA, Stearns RC, Lawrence J, Murthy GG, DiazE, Koutrakis P, Suh H, Tsuda A, Godleski JJ: Lung inflammation induced by concentrated ambient air particles is related to particle composition. Am J Respir Crit Care Med 2002, 165:1610-1617.

20. IARC: Cobalt in Hard Metals and Cobalt Sulfate, Gallium Arsenide, Indium Phosphide and Vanadium Pentoxide Lyon, France: International Agency for Research on Cancer (IARC); 2006

21. Sadiq M, Mian AA: Nickel and Vanadium in Air Particulates at Dhahran (Saudi-Arabia) During and after the Kuwait Oil Fires. Atmospheric Environment 1994, 28:2249-2253.

22. Hauser R, Eisen EA, Pothier L, Christiani DC: A prospective study of lung function among boilermaker construction workers exposed to combustion particulates. Am J Ind Med 2001, 39:454-462.

23. Hauser R, Eisen EA, Pothier L, Lewis D, Bledsoe T, Christiani DC: Spirometric abnormalities associated with chronic bronchitis, asthma, and airway hyperresponsiveness among boilermaker construction workers. Chest 2002, 121:2052-2060.

24. Irsigler GB, Visser PJ, Spangenberg PA: Asthma and chemical bronchitis in vanadium plant workers. Am J Ind Med 1999, 35:366-374.

25. Hauser R, Elreedy S, Hoppin JA, Christiani DC: Upper airway response in workers exposed to fuel oil ash: nasal lavage analysis. Occup Environ Med 1995, 52:353-358.

26. Knecht EA, Moorman WJ, Clark JC, Lynch DW, Lewis TR: Pulmonary effects of acute vanadium pentoxide inhalation in monkeys. Am Rev Respir Dis 1985, 132:1181-1185.

27. Bonner JC, Rice AB, Ingram JL, Moomaw CR, Nyska A, Bradbury A, Sessoms AR, Chulada PC, Morgan DL, Zeldin DC, Langenbach R: Susceptibility of cyclooxygenase-2-deficient mice to pulmonary fibrogenesis. Am J Pathol 2002, 161:459-470.

28. Bonner JC, Rice AB, Moomaw CR, Morgan DL: Airway fibrosis in rats induced by vanadium pentoxide. Am J Physiol Lung Cell Mol Physiol 2000, 278:L209-216

29. Pierce LM, Alessandrini F, Godleski JJ, Paulauskis JD: Vanadium-induced chemokine mRNA expression and pulmonary inflammation. Toxicol Appl Pharmacol 1996, 138:1-11.

30. Ress NB, Chou BJ, Renne RA, Dill JA, Miller RA, Roycroft JH, Hailey JR, Haseman JK, Bucher JR: Carcinogenicity of inhaled vanadium pentoxide in F344/N rats and B6C3F1 mice. Toxicol Sci 2003, 74:287-296.

31. Ehrlich VA, Nersesyan AK, Hoelzi C, Ferk F, Bichler J, Valic E, Schaffer A, Schulte-Hermann R, Fenech M, Wagner KH, Knasmuller S: Inhalative Exposure to Vanadium Pentoxide Causes DNA Damage in Workers: Results of a Multiple End Point Study. Environmental Health Perspectives 2008, 116:1689-1693.

32. Sorensen M, Schins RP, Hertel O, Loft S: Transition metals in personal samples of PM2.5 and oxidative stress in human volunteers. Cancer Epidemiol Biomarkers Prev 2005, 14:1340-1343.

33. Hickey RJ, Schoff EP, Clelland RC: Relationship between air pollution and certain chronic disease death rates. Multivariate statistical studies. Arch Environ Health 1967, 15:728-738.

34. Boice JD, Mumma MT, Blot WJ: Cancer and noncancer mortality in populations living near uranium and vanadium mining and milling operations in Montrose County, Colorado, 1950-2000. Radiation Research 2007, 167:711-726.

35. Rivedal E, Roseng LE, Sanner T: Vanadium compounds promote the induction of morphological transformation of hamster embryo cells with no effect on gap junctional cell communication. Cell Biol Toxicol 1990, 6:303-314. 
36. Bauer AK, Malkinson AM, Kleeberger SR: Susceptibility to neoplastic and non-neoplastic pulmonary diseases in mice: genetic similarities. Am J Physiol Lung Cell Mol Physiol 2004, 287:L685-703.

37. Bauer AK, Dwyer-Nield LD, Keil K, Koski K, Malkinson AM: Butylated hydroxytoluene (BHT) induction of pulmonary inflammation: a role in tumor promotion. Exp Lung Res 2001, 27:197-216.

38. Malkinson AM, Radcliffe RA, Bauer AK: Quantitative trait locus mapping of susceptibilities to butylated hydroxytoluene-induced lung tumor promotion and pulmonary inflammation in CXB mice. Carcinogenesis 2002, 23:411-417.

39. Miller YE, Dwyer-Nield LD, Keith RL, Le M, Franklin WA, Malkinson AM: Induction of a high incidence of lung tumors in C57BL/6 mice with multiple ethyl carbamate injections. Cancer Lett 2003, 198:139-144.

40. Ewart SL, Kuperman D, Schadt E, Tankersley C, Grupe A, Shubitowski DM, Peltz G, Wills-Karp M: Quantitative trait loci controlling allergen-induced airway hyperresponsiveness in inbred mice. Am J Respir Cell Mol Biol 2000, 23:537-545.

41. Lewkowich IP, Lajoie S, Clark JR, Herman NS, Sproles AA, Wills-Karp M: Allergen uptake, activation, and IL-23 production by pulmonary myeloid DCs drives airway hyperresponsiveness in asthma-susceptible mice. PLoS One 2008, 3:e3879.

42. Bauer AK, Dwyer-Nield LD, Hankin JA, Murphy RC, Malkinson AM: The lung tumor promoter, butylated hydroxytoluene (BHT), causes chronic inflammation in promotion-sensitive BALB/CByJ mice but not in promotion-resistant CXB4 mice. Toxicology 2001, 169:1-15.

43. Foster WM, Walters DM, Longphre M, Macri K, Miller LM: Methodology for the measurement of mucociliary function in the mouse by scintigraphy. J Appl Physiol 2001, 90:1111-1117.

44. Cho HY, Jedlicka AE, Reddy SP, Kensler TW, Yamamoto M, Zhang LY, Kleeberger SR: Role of NRF2 in protection against hyperoxic lung injury in mice. Am J Respir Cell Mol Biol 2002, 26:175-182.

45. Ainbinder E, Bergelson S, Pinkus R, Daniel V: Regulatory mechanisms involved in activator-protein-1 (AP-1)-mediated activation of glutathione-S-transferase gene expression by chemical agents. Eur J Biochem 1997, 243:49-57.

46. Bergelson S, Pinkus R, Daniel V: Intracellular glutathione levels regulate Fos/Jun induction and activation of glutathione S-transferase gene expression. Cancer Res 1994, 54:36-40.

47. Kwon YW, Ueda S, Ueno M, Yodoi J, Masutani H: Mechanism of p53dependent apoptosis induced by 3-methylcholanthrene: involvement of 553 phosphorylation and p38 MAPK. J Biol Chem 2002, 277:1837-1844

48. Bauer AK, Dixon D, DeGraff $L M, C h o H Y$, Walker CR, Malkinson AM, Kleeberger SR: Toll-like receptor 4 in butylated hydroxytolueneinduced mouse pulmonary inflammation and tumorigenesis. $J$ Natl Cancer Inst 2005, 97:1778-1781

49. Coussens LM, Werb Z: Inflammation and cancer. Nature 2002, 420:860-867.

50. Engels EA: Inflammation in the development of lung cancer: epidemiological evidence. Expert Rev Anticancer Ther 2008, 8:605-615.

51. Bauer AK, Rondini EA: Review paper: the role of inflammation in mouse pulmonary neoplasia. Vet Pathol 2009, 46:369-390.

52. Ji H, Houghton AM, Mariani TJ, Perera S, Kim CB, Padera R, Tonon G, McNamara K, Marconcini LA, Hezel A, et al.: K-ras activation generates an inflammatory response in lung tumors. Oncogene 2006, 25:2105-2112.

53. Wislez M, Fujimoto N, Izzo JG, Hanna AE, Cody DD, Langley RR, Tang H, Burdick MD, Sato M, Minna JD, et al.: High expression of ligands for chemokine receptor CXCR2 in alveolar epithelial neoplasia induced by oncogenic kras. Cancer Res 2006, 66:41 98-4207.

54. Festing MF, Lin L, Devereux TR, Gao F, Yang A, Anna CH, White CM, Malkinson AM, You M: At least four loci and gender are associated with susceptibility to the chemical induction of lung adenomas in $A / J \times$ BALB/c mice. Genomics 1998, 53:129-136.

55. Obata M, Nishimori H, Ogawa K, Lee GH: Identification of the Par2 (Pulmonary adenoma resistance) locus on mouse chromosome 18, a major genetic determinant for lung carcinogen resistance in BALB/ cByJ mice. Oncogene 1996, 13:1599-1604.

56. Wang L, Medan D, Mercer R, Overmiller D, Leornard S, Castranova V, Shi X, Ding M, Huang C, Rojanasakul Y: Vanadium-induced apoptosis and pulmonary inflammation in mice: Role of reactive oxygen species. J Cell Physiol 2003, 195:99-107.
57. Wang $Y Z$, Ingram JL, Walters DM, Rice AB, Santos JH, Van Houten $B$, Bonner JC: Vanadium-induced STAT-1 activation in lung myofibroblasts requires $\mathrm{H}_{2} \mathrm{O}_{2}$ and P38 MAP kinase. Free Radic Biol Med 2003, 35:845-855.

58. Grabowski GM, Paulauskis JD, Godleski JJ: Mediating phosphorylation events in the vanadium-induced respiratory burst of alveolar macrophages. Toxicol Appl Pharmacol 1999, 156:170-178.

59. Huang C, Chen N, Ma WY, Dong Z: Vanadium induces AP-1- and NFkappB-dependent transcription activity. Int J Oncol 1998, 13:711-715

60. Ingram JL, Rice AB, Santos J, Van Houten B, Bonner JC: Vanadium-induced HB-EGF expression in human lung fibroblasts is oxidant dependent and requires MAP kinases. Am J Physiol Lung Cell Mol Physiol 2003, 284:L774-782.

61. Wang YZ, Bonner JC: Mechanism of extracellular signal-regulated kinase (ERK)- 1 and ERK-2 activation by vanadium pentoxide in rat pulmonary myofibroblasts. Am J Respir Cell Mol Biol 2000, 22:590-596

62. Samet JM, Graves LM, Quay J, Dailey LA, Devlin RB, Ghio AJ, Wu W, Bromberg PA, Reed W: Activation of MAPKs in human bronchial epithelial cells exposed to metals. Am J Physiol 1998, 275:L551-558.

63. Chen F, Demers LM, Vallyathan V, Ding M, Lu Y, Castranova V, Shi X: Vanadate induction of NF-kappaB involves IkappaB kinase beta and SAPK/ERK kinase 1 in macrophages. J Biol Chem 1999, 274:20307-20312.

64. Ding M, Li JJ, Leonard SS, Ye JP, Shi X, Colburn NH, Castranova V, Vallyathan $\mathrm{V}$ : Vanadate-induced activation of activator protein-1: role of reactive oxygen species. Carcinogenesis 1999, 20:663-668.

65. Antao-Menezes A, Turpin EA, Bost PC, Ryman-Rasmussen JP, Bonner JC: STAT-1 signaling in human lung fibroblasts is induced by vanadium pentoxide through an IFN-beta autocrine loop. J Immunol 2008, 180:4200-4207.

66. Samet JM, Silbajoris R, Wu W, Graves LM: Tyrosine phosphatases as targets in metal-induced signaling in human airway epithelial cells. Am J Respir Cell Mol Biol 1999, 21:357-364.

67. Carter JD, Ghio AJ, Samet JM, Devlin RB: Cytokine production by human airway epithelial cells after exposure to an air pollution particle is metal-dependent. Toxicol Appl Pharmacol 1997, 146:180-188.

68. Chong IW, Shi MM, Love JA, Christiani DC, Paulauskis JD: Regulation of chemokine mRNA expression in a rat model of vanadium-induced pulmonary inflammation. Inflammation 2000, 24:505-517.

69. Huang S, Paulauskis JD, Kobzik L: Rat KC cDNA cloning and mRNA expression in lung macrophages and fibroblasts. Biochem Biophys Res Commun 1992, 184:922-929.

70. Matsushima K, Larsen CG, DuBois GC, Oppenheim JJ: Purification and characterization of a novel monocyte chemotactic and activating factor produced by a human myelomonocytic cell line. J Exp Med 1989, 169:1485-1490.

71. Gungor N, Pennings JL, Knaapen AM, Chiu RK, Peluso M, Godschalk RW, van Schooten FJ: Transcriptional profiling of the acute pulmonary inflammatory response induced by LPS: role of neutrophils. Respir Res 2010, 11:24

72. de Visser KE, Eichten A, Coussens LM: Paradoxical roles of the immune system during cancer development. Nat Rev Cancer 2006, 6:24-37.

73. Zhu YM, Webster SJ, Flower D, Woll PJ: Interleukin-8/CXCL8 is a growth factor for human lung cancer cells. Br J Cancer 2004, 91:1970-1976.

74. Luppi F, Longo AM, de Boer WI, Rabe KF, Hiemstra PS: Interleukin-8 stimulates cell proliferation in non-small cell lung cancer through epidermal growth factor receptor transactivation. Lung Cancer 2007, 56:25-33.

75. de Boer WI, Sont JK, van Schadewijk A, Stolk J, van Krieken JH, Hiemstra PS: Monocyte chemoattractant protein 1 , interleukin 8 , and chronic airways inflammation in COPD. J Pathol 2000, 190:619-626.

76. Tomaki M, Sugiura H, Koarai A, Komaki Y, Akita T, Matsumoto T, Nakanishi A, Ogawa H, Hattori T, Ichinose M: Decreased expression of antioxidant enzymes and increased expression of chemokines in COPD lung. Pulm Pharmacol Ther 2007, 20:596-605.

77. Arenberg DA, Keane MP, DiGiovine B, Kunkel SL, Strom SR, Burdick MD, lannettoni MD, Strieter RM: Macrophage infiltration in human nonsmall-cell lung cancer: the role of CC chemokines. Cancer Immunol Immunother 2000, 49:63-70.

78. Chapman RW, Minnicozzi M, Celly CS, Phillips JE, Kung TT, Hipkin RW, Fan $X$, Rindgen $D$, Deno $G$, Bond $R$, et al:: A novel, orally active CXCR1/2 receptor antagonist, Sch52 inhibits neutrophil recruitment, mucus 
production, and goblet cell hyperplasia in animal models of pulmonary inflammation. J Pharmacol Exp Ther 2007, 322:486-493.

79. Keane MP, Belperio JA, Xue YY, Burdick MD, Strieter RM: Depletion of CXCR2 inhibits tumor growth and angiogenesis in a murine model of lung cancer. J Immunol 2004, 172:2853-2860.

80. Sparmann A, Bar-Sagi D: Ras-induced interleukin-8 expression plays a critical role in tumor growth and angiogenesis. Cancer Cell 2004, 6:447-458.

81. Ji H, Wang Z, Perera SA, Li D, Liang MC, Zaghlul S, McNamara K, Chen L, Albert M, Sun Y, et al:: Mutations in BRAF and KRAS converge on activation of the mitogen-activated protein kinase pathway in lung cancer mouse models. Cancer Res 2007, 67:4933-4939.

82. Roberts PJ, Der CJ: Targeting the Raf-MEK-ERK mitogen-activated protein kinase cascade for the treatment of cancer. Oncogene 2007, 26:3291-3310

83. Stathopoulos GT, Sherrill TP, Cheng DS, Scoggins RM, Han W, Polosukhin W, Connelly L, Yull FE, Fingleton B, Blackwell TS: Epithelial NF-kappaB activation promotes urethane-induced lung carcinogenesis. Proc Natl Acad Sci USA 2007, 104:18514-18519.

84. Angel P, Karin M: The role of Jun, Fos and the AP-1 complex in cellproliferation and transformation. Biochim Biophys Acta 1991, 1072:129-157.

85. Devereux TR, Holliday W, Anna C, Ress N, Roycroft J, Sills RC: Map kinase activation correlates with K-ras mutation and loss of heterozygosity on chromosome 6 in alveolar bronchiolar carcinomas from B6C3F1 mice exposed to vanadium pentoxide for 2 years. Carcinogenesis 2002, 23:1737-1743.

doi: 10.1186/1743-8977-7-9

Cite this article as: Rondini et al. Vanadium pentoxide induces pulmonary inflammation and tumor promotion in a strain-dependent manner Particle and Fibre Toxicology 2010, 7:9

Submit your next manuscript to BioMed Central and take full advantage of:

- Convenient online submission

- Thorough peer review

- No space constraints or color figure charges

- Immediate publication on acceptance

- Inclusion in PubMed, CAS, Scopus and Google Scholar

- Research which is freely available for redistribution

Submit your manuscript at www.biomedcentral.com/submit
Ciomed Central 